\title{
RELASI SOSIAL DALAM PRAKTIK KEBIJAKAN CSR
}

\author{
Miftah Faridl Widhagdha ${ }^{* 1}$, Hermin Indah Wahyuni ${ }^{2}$, Muhammad Sulhan ${ }^{3}$ \\ ${ }^{1}$ Prodi Penyuluhan dan Komunikasi Pembangunan, Universitas Gadjah Mada, \\ Yogyakarta, Indonesia \\ Email: arjuna.miftah@gmail.com \\ ${ }^{2}$ Pusat Studi Sosial Asia Tenggara, Universitas Gadjah Mada, Yogyakarta, Indonesia \\ Email: hermin_iw@ugm.ac.id \\ ${ }^{3}$ Prodi Ilmu Komunikasi, Universitas Gadjah Mada, Yogyakarta, Indonesia \\ Email: hansul@ugm.ac.id
}

\begin{abstract}
Abstrak
Penelitian ini beranjak dari terbatasnya kajian CSR (Corporate Social Responsibility) pada masyarakat penerima manfaat di Indonesia. Teori yang diadaptasi dalam penelitian ini adalah teori modal sosial oleh Woolcock \& Narayan. Metode penelitian dalam penelitian ini adalah kualitatif dengan pendekatan deskriptif interpretif model Neuman. Penelitian ini menelaah bentuk-bentuk modal sosial dalam berbagai bentuk relasi sosial. Hasil penelitian ini menunjukkan bahwa terdapat beragam bentuk relasi sosial yang ada di masyarakat, yaitu bonding, bridging dan linking. Relasi bonding menunjukkan bahwa ikatan intra kelompok penting untuk diperhatikan guna menjaga kekompakan kelompok. Relasi bridging menunjukkan bahwa ikatan antar kelompok perlu dibangun guna terjalin kerja sama antara kelompok binaan dengan kelompok binaan lain. Sedangkan relasi linking menunjukkan bahwa adanya dampak yang baik bagi kelompok-kelompok yang memiliki kedekatan hubungan dengan lembaga kekuasaan yang lebih tinggi. Hasil ini menunjukkan bahwa ketiga bentuk relasi sosial memiliki dampak terhadap pelaksanaan CSR di suatu perusahaan. Relasi ini penting untuk dijaga melalui kegiatan komunikasi yang bertujuan untuk pembangunan yang dilakukan melalui cara-cara yang lebih intensif, terbuka dan partisipatif guna melahirkan relasi sosial yang sehat dan berkelanjutan.
\end{abstract}

Kata kunci: CSR, komunikasi pembangunan, modal sosial, relasi social

\begin{abstract}
This research moved from the limited study of CSR (Corporate Social Responsibility) to beneficiary communities in Indonesia. The theory adapted in this study is the theory of social capital by Woolcock \& Narayan. The research method in this study was qualitative with the interpretive descriptive approach of the Neuman model. This study examines forms of social capital in various forms of social relations. The results of this study indicate that there are various forms of social relations that exist in society, namely bonding, bridging and linking.relations Bonding show that intra-group bonds are important to consider in order to maintain group cohesiveness.relations Bridging show that ties between groups need to be built in order to establish cooperation between the target groups and other target groups. Whereasrelations linking indicate that there is a good impact for groups that have a closer relationship with higher power institutions. These results indicate that the three forms of social relations have an impact on the implementation of CSR in a company. This relationship is important to be maintained through communication activities aimed at development carried out through more intensive, open and participatory ways to create healthy and sustainable social relations.
\end{abstract}

Keywords: CSR, development communication, social capital, social relations

Submited: 04-02-2018; Accepted: 25-04-2019; Published: 30-04-2019

*Korespondensi: Prodi Penyuluhan dan Komunikasi Pembangunan, Universitas Gadjah Mada, Bulaksumur, Caturtunggal, Depok, Sleman, Daerah Istimewa Yogyakarta 55281

Email: arjuna.miftah@gmail.com 
106| The Journal of Society and Media 3(1)

\section{PENDAHULUAN}

Tanggung jawab sosial perusahaan (Corporate Social Responsibility, selanjutnya disebut CSR) kian menjadi perbincangan serius dalam forum-forum korporasi global dalam beberapa tahun terakhir. Di Indonesia, perbincangan mengenai CSR tidak hanya didominasi oleh korporasi global saja, namun sudah masuk pada perbincangan korporasi milik negara dan swasta nasional yang mulai serius dalam menggarap program - program CSR mereka demi mendukung terbentuknya citra perusahaan yang positif (Colemen 1999). Salah satu pengungkitnya adalah meningkatnya kepedulian terhadap isu - isu lingkungan seperti perubahan iklim yang telah mendorong terciptanya banyak peraturan, kesepakatan dan konvensi tentang pentingnya peran korporasi dalam menjaga keselamatan dan kelestarian lingkungan. Upaya untuk memberi perhatian lebih pada aspek lingkungan ini didukung dengan adanya realitas bahwa keberadaan lingkungan tidak pernah bisa lepas dari keberadaan masyarakat lokal yang berada di lingkungan tersebut. Sehingga wacana tentang kelestarian lingkungan dan masyarakat lokal terus menjadi perbincangan dalam beberapa dekade terakhir.

Namun, meski wacana tentang pelibatan masyarakat lokal dalam praktik CSR telah digaungkan dalam berbagai diskusi baik di level nasional maupun internasional, pada kenyataannya masyarakat lokal masih sering kali ditinggalkan dalam pelaksanaan CSR terutama pada bidang lingkungan. Korporasi sering kali abai terhadap relasi sosial dan mekanisme sosial yang ada di masyarakat, sehingga upaya pelestarian lingkungan melalui penguatan peran masyarakat banyak menemui kegagalan (Elkington 1997).

Hal penting yang juga sering kali dilupakan dan membuat CSR semakin menjadi paradoks terutama di kalangan masyarakat lokal adalah adanya ketidakpercayaan (distrust) yang timbul karena korporasi terlalu banyak memasukkan kepentingan korporasi seperti pemasaran dan pembentukan citra perusahaan (Corporate Marketing Responsibilities) dibandingkan dengan upaya menghadirkan solusi yang benar - benar dibutuhkan masyarakat atas permasalahan yang dihadapi. Hal ini diungkapkan Edelman dalam laporannya pada tahun 2009 yang menyimpulkan bahwa pemangku kepentingan terutama masyarakat kehilangan kepercayaannya terhadap upaya tanggung jawab sosial yang dilakukan oleh korporasi karena banyaknya kepentingan yang dimasukkan 
dalam aktivitas CSR seperti pemasaran, pelepasan tanggung jawab dan public relations spin (Edelman, 2009; Jahdi \& Acikdilli, 2009).

Maka sebagai salah satu cara untuk mendapatkan kembali kepercayaan publik terutama masyarakat lokal yang berada di sekitar operasi perusahaan, sudah sepantasnya apabila korporasi mulai memikirkan strategi untuk menjalin kembali relasi yang ada dan saling percaya antara korporasi dengan masyarakat maupun terlibat lebih jauh dalam relasi sosial yang terjadi di antara masyarakat yang berada di sekitar wilayah operasi perusahaan guna mendapatkan gambaran yang tepat dan menyeluruh mengenai kondisi sosial masyarakat. Gambaran yang holistik ini dapat dijadikan landasan dalam merancang program CSR yang akan dilakukan perusahaan kepada masyarakat yang menjadi mitra binaan perusahaan melalui program CSR. Sehingga program CSR yang dilakukan oleh perusahaan dapat benar - benar memberikan dampak yang berkelanjutan bagi kehidupan masyarakat lokal dan meraih kembali kepercayaan para pemangku kepentingan.

PT Pertamina (Persero) melalui salah satu wilayah operasionalnya yaitu PT Pertamina Refinery Unit II Kilang Sungai Pakning yang berada di Kelurahan Sungai Pakning, Kecamatan Bukit Batu, Kabupaten Bengkalis, Provinsi Riau merupakan salah satu korporasi yang melaksanakan CSR sebagai bentuk tanggung jawab sosial dan lingkungan. Kajian ini hendak melihat bagaimana relasi sosial terbentuk dalam masyarakat binaan CSR PT Pertamina RU II Kilang Sungai Pakning sehingga mampu memberi gambaran mengenai aspek sosial yang mempengaruhi dinamika sosial dalam pengelolaan CSR yang berkelanjutan.

Memahami aspek sosial sebagai salah satu jembatan dalam pelaksanaan CSR setidaknya sudah banyak dilakukan oleh para ilmuwan sebelumnya. Pelaksanaan CSR dianggap memiliki dampak sosial yang signifikan dalam relasi yang timbul antara korporasi dengan masyarakat (Werther.J, Chandler 2011), selain itu pelaksanaan CSR juga dianggap mampu meredam berbagai konflik lokal yang mungkin terjadi antara korporasi dengan masyarakat (Waddock,S. Googins 2011). Relasi sosial dalam penelitian ini berfokus pada tiga tipe relasi sosial yaitu relasi bonding, bridging dan linking sebagai bentuk dari modal sosial. (Woolcock 1998), kemudian menjelaskan mengenai modal sosial sebagai manifestasi dari relasi sosial (Cortado,F., Chalmeta 2016), pendekatan ini melihat pentingnya akses yang dimiliki individu dalam tatanan sosial yang ada, maka para 
ilmuwan kemudian memperkenalkan tiga tipe relasi sosial yaitu bonding, bridging dan linking. Masing-masing relasi sosial ini menjelaskan modal sosial berdasarkan akses yang dimiliki individu dalam masyarakat. Relasi bonding untuk menjelaskan relasi yang timbul di kalangan komunitas homogen secara horizontal, relasi bridging menjelaskan relasi sosial yang timbul di kalangan komunitas heterogen secara horizontal, sedangkan relasi linking menjelaskan relasi sosial yang timbul antar level kalangan dalam komunitas secara vertikal.

Dari pemaparan tersebut, peneliti kemudian tertarik untuk lebih dalam mengulas ketiga tipe relasi sosial yaitu relasi bonding, bridging dan linking dalam dinamika sosial yang terjadi di masyarakat binaan CSR PT Pertamina RU II Kilang Sungai Pakning. Penelitian terhadap topik ini diharapkan mampu memberikan deskripsi mengenai bentuk dan karakteristik relasi sosial bonding, bridging dan linking dalam masyarakat binaan CSR PT Pertamina RU II Kilang Sungai Pakning dan dampaknya dalam pelaksanaan CSR PT Pertamina RU II Kilang Sungai Pakning.

\section{METODE PENELITIAN}

Penelitian ini merupakan penelitian kualitatif dengan pendekatan deskriptif interpretif dan variasi fenomenologis seperti yang diperkenalkan Neuman (Neuman 2013) dan Qudsy (Qudsy 2015). Dari upaya interpretif diharapkan dapat memahami dan menjelaskan makna yang terkandung dalam tindakan sosial di masyarakat melalui sistem makna yang dibuat dan dipertahankan oleh masyarakat (Mutiah 2017). Sedangkan variasi fenomenologis diharapkan untuk mencari esensi makna dari suatu fenomena yang dialami oleh beberapa individu. Pendekatan ini juga berusaha untuk mendeskripsikan pemaknaan umum (theorizing) dari sejumlah individu terhadap berbagai pengalaman hidup mereka terkait suatu konsep atau fenomena (Woolcock 2002). Pengalaman hidup sejumlah individu ini menjadi objektif ketika informan penelitian secara sadar mengetahui sesuatu yang khas dari fenomena yang ada. Namun kesadaran ini tidak berarti terpaku pada penafsiran informan atas makna yang dituturkan dalam wawancara mendalam, namun bisa juga bersumber dari penafsiran peneliti sebagai upaya mediasi antara makna yang secara esensi sama namun diungkapkan berbeda melalui observasi yang ketat. 
Lokasi penelitian ditentukan berdasarkan metode purposive yaitu pendekatan yang digunakan pada populasi yang memiliki daerah dengan karakteristik tertentu dan terdapat unsur kesengajaan dalam penentuannya. Lokasi yang dipilih dalam penelitian ini adalah wilayah CSR Pertamina RU II Kilang Sungai Pakning. PT. Pertamina RU II Kilang Sungai Pakning merupakan salah satu perusahaan minyak dan gas di Indonesia dengan jenis kegiatan pengolahan minyak mentah dengan wilayah kerja CSR yang meliputi 1 (satu) Kelurahan Sungai Pakning dan 4 (Empat) Desa yaitu Desa Sejangat, Desa Pakning Asal, Desa Sungai Selari dan Desa Batang Duku. Masing - masing wilayah menjadi tempat pelaksanaan Program CSR yang berbeda - beda dengan menyesuaikan pada kondisi lingkungan, tingkat ekonomi dan dinamika sosial masyarakat di masing - masing wilayah tersebut, sehingga perlu diketahui informasi yang lebih memdalam khususnya mengenai relasi modal sosial dan kaitannya dalam pelaksanaan aktifitas CSR perusahaan.

Pemilihan informan dalam penelitian ini menggunakan metode purposive, yaitu melalui pemilihan informan yang dirasa memiliki hubungan dengan tujuan penelitian dan dianggap cukup mengetahui tentang permasalahan penelitian. Informan dalam penelitian ini adalah anggota kelompok binaan CSR PT Pertamina RU II Kilang Sungai Pakning yang terdiri dari Kelompok Tani Tunas Makmur, Kelompok Masyarakat Peduli Api Desa Sungai Selari dan Kelompok Nelayan Harapan Bersama sedangkan informan lain adalah staf CSR PT Pertamina RU II Kilang Sungai Pakning dan Lurah Kelurahan Sungai Pakning. Informan dalam penelitian ini memberikan informasi terkait kondisi relasi sosial yang ada di masyarakat yang menjadi topik penelitian ini.

\section{HASIL DAN PEMBAHASAN}

\section{Relasi Bonding Masyarakat Binaan}

Relasi bonding yang ada di masyarakat dapat berupa dua kategori besar yaitu Struktural (Structural Form) dan Kognitif (Cognitive Form). Relasi bonding struktural merupakan bentuk relasi yang didasari karena aturan-aturan yang mengatur peran anggotanya dalam mencapai tujuan bersama, sedangkan relasi bonding kognitif merupakan relasi yang didasari pada kesamaan nilai dan norma, kepercayaan dan sikap sosial untuk mencapai tujuan bersama. Relasi bonding 
kognitif menunjukkan adanya nilai-nilai komunitarian (communitarism) yang mengedepankan kesamaan tata nilai dan ideologi yang ada dalam suatu kelompok. Dalam nilai-nilai komunitarian, relasi bonding menunjukkan adanya kohesi sosial yang erat dengan ditunjukkan melalui adanya harmonisasi antar anggota dalam suatu kelompok.

Tabel 1: Bentuk dan Karakteristik Relasi Bonding Masyarakat Binaan CSR PT Pertamina (Persero) RU II Kilang Sungai Pakning (Edelmen 2018)

\begin{tabular}{|c|c|c|c|c|}
\hline No & Karakteristik & Kelompok & MPA Desa & Kelompok \\
\hline & $\begin{array}{l}\text { Relasi } \\
\text { Bonding }\end{array}$ & $\begin{array}{l}\text { Tani Tunas } \\
\text { Makmur }\end{array}$ & Sungai Selari & $\begin{array}{l}\text { Nelayan Harapan } \\
\text { Bersama }\end{array}$ \\
\hline 1 & Kategori Relasi & $\begin{array}{l}\text { Campuran } \\
\text { Struktural } \quad- \\
\text { Kognitif }\end{array}$ & Struktural & Kognitif \\
\hline 2 & $\begin{array}{l}\text { Bentuk } \\
\text { Kelembagaan }\end{array}$ & Formal & Formal & Formal \\
\hline 3 & $\begin{array}{l}\text { Bentuk } \\
\text { Kesamaan }\end{array}$ & $\begin{array}{l}\text { Kekerabatan / } \\
\text { Kekeluargaan }\end{array}$ & Kewilayahan & $\begin{array}{l}\text { Kewilayahan } \\
\text { Profesi }\end{array}$ \\
\hline 4 & $\begin{array}{l}\text { Bentuk Forum } \\
\text { Pengambilan } \\
\text { Keputusan }\end{array}$ & $\begin{array}{l}\text { Musyawarah } \\
\text { \& Rapat }\end{array}$ & $\begin{array}{l}\text { Rapat \& } \\
\text { Instruksi } \\
\text { Kepala Desa }\end{array}$ & $\begin{array}{l}\text { Musyawarah } \\
\text { Rapat }\end{array}$ \\
\hline 5 & $\begin{array}{l}\text { Bentuk } \\
\text { Peraturan }\end{array}$ & $\begin{array}{l}\text { AD/ART, } \\
\text { Konsensus }\end{array}$ & $\begin{array}{l}\text { SK Kepala } \\
\text { Desa, } \\
\text { Konsensus }\end{array}$ & $\begin{array}{l}\text { Konsensus, Adat } \\
\text { Istiadat }\end{array}$ \\
\hline 6 & $\begin{array}{l}\text { Bentuk } \\
\text { Penguatan } \\
\text { Bonding }\end{array}$ & Royong & Patroli & Turun Kapal \\
\hline 7 & Tokoh Kunci & $\begin{array}{l}\text { Ketua } \\
\text { Kelompok }\end{array}$ & $\begin{array}{l}\text { Kepala Desa, } \\
\text { Ketua } \\
\text { Kelompok }\end{array}$ & $\begin{array}{l}\text { Ketua Kelompok, } \\
\text { Tokoh Kampung, } \\
\text { Imam Masjid }\end{array}$ \\
\hline
\end{tabular}

\section{Bonding pada Kelompok Tani Tunas Makmur}

Pada Kelompok Tani Tunas Makmur bentuk dan karakteristik relasi bonding dapat diamati melalui adanya kedekatan kekeluargaan yang terdapat di hampir semua anggota kelompok. Dari 31 anggota kelompok, mayoritas anggotanya merupakan famili besar yang sejak lama tinggal di wilayah tersebut. Mayoritas dari mereka merupakan anak keturunan transmigran Jawa yang merantau ke Sumatera pada periode tahun 1950-1960an.

Sejak pembentukan kelompok hingga saat ini, pertambahan jumlah anggota lebih banyak terjadi pada kerabat dekat atau warga yang memang tinggal dekat dengan lokasi kelompok. Karena karakteristiknya yang berdasarkan kekerabatan dan kekeluargaan, maka koordinasi yang dilakukan pun menjadi relatif lebih mudah karena jarak rumah antar anggota yang berdekatan dan komunikasi informal yang terjalin sebelumnya sudah cukup kuat. Karakteristik ini 
menunjukkan adanya tradisi komunitarian yang kuat merujuk pada apa yang dikatakan Putnam (Putnam 1993) tentang tradisi komunitarian yang mengedepankan aspek-aspek kekerabatan dan kesamaan tata nilai atau norma yang ada dalam masyarakat. Tradisi komunitarian ini juga tercermin dari masih adanya kearifan lokal yaitu Royong (Gotong Royong) di masyarakat. Keberadaan kearifan lokal ini terlihat dari adanya kemauan secara sukarela untuk membantu meringkankan pekerjaan anggota lain yang sedang ditimpa musibah atau dari kemauan untuk terlibat untuk membantu anggota yang sedang mengadakan pesta kenduri.

Namun di sisi lain, karena mayoritas anggota kelompok merupakan kerabat atau keluarga besar, hal ini mengakibatkan kelompok lebih selektif dalam menerima anggota baru di luar kelompok mereka. Hal ini sesuai dengan kecenderungan karakteristik relasi bonding yang memunculkan sikap protektif kelompok. Keberadaan sikap protektif ini merupakan bentuk dari perlindungan terhadap kelompok inti dari keberadaan anggota yang tidak berasal dari latar belakang yang sama (out Group) sehingga dapat meminimalisasi konflik yang timbul karena perbedaan latar belakang. Sikap ini bisa dilihat sebagai bentuk menjaga kekompakan dan soliditas yang ada di Kelompok mengingat keberadaan kelompok yang berada di wilayah cukup terpencil dan jauh dari pusat kota, maka pilihan untuk menjaga kualitas kelompok dengan cara menguatkan sikap kesaling percayaan (Trust) menjadi salah satu strategi untuk menjaga relasi bonding yang ada tetap kuat.

\section{Bonding pada Kelompok Masyarakat Peduli Api Desa Sungai Selari}

Kelompok Masyarakat Peduli Api Desa Sungai Selari merupakan kelompok yang dibentuk oleh Kepala Desa Sungai Selari untuk merespon penanggulangan kebakaran lahan dan hutan yang terjadi di wilayah tersebut. Pembentukan anggotanya pun didasarkan pada perekrutan warga masyarakat yang bersedia untuk bertugas melakukan patroli dan pemadaman kebakaran tahap awal sehingga sifat kelompoknya lebih struktural. Karena sifatnya yang lebih struktural, kelompok ini lebih menekankan pada peraturan yang dibuat oleh Kepala Desa sebagai peraturan bersama yang harus disepakati oleh anggota. Keberadaan Kepala Desa juga memiliki peran penting dalam menjaga soliditas anggota karena 
kelompok melakukan koordinasi dan konsultasi kepada Kepala Desa apabila mengalami masalah-masalah yang tidak bisa diselesaikan sendiri oleh kelompok.

Kedekatan yang terbangun antar anggota kelompok juga didasarkan pada kesamaan keanggotaan dan kedekatan yang terjadi karena kesamaan wilayah domisili bukan karena adanya kedekatan informal yang bersifat homogen. Apalagi masing-masing anggota kelompok menunjukkan latar belakang kesukuan yang berbeda-beda, mulai dari suku Melayu, Jawa hingga Batak. Karakteristik ini sebenarnya menunjukkan lemahnya relasi bonding yang ada di kelompok tersebut karena tidak dibangun di atas keintiman dan informalitas yang menjadi ciri khas relasi bonding.

Lemahnya relasi bonding antar anggota juga berdampak pada terbatasnya kerja bersama (collective Action) yang didasari pada kesukarelaan (voluntary) yang menjadi ciri khas relasi bonding dalam sebuah jejaring sosial (Social Networks). Masing-masing anggota juga cenderung tidak menunjukkan adanya kepedulian terhadap masalah yang dialami oleh anggota lain, mengingat permasalahan yang timbul lebih sering diserahkan kepada Kepala Desa untuk dapat memutuskan kebijakan yang ada diberlakukan. Faktor yang masih menguatkan keberadaan relasi bonding pada kelompok MPA Desa Sungai Selari salah satunya adalah pada kehadiran rapat (meetingattendance) dan tujuan kelompok (Communityorientation) yang masih dapat terjaga dengan baik karena memang kelompok ini terbentuk untuk tujuan khusus dan spesifik seperti patroli dan pemadaman kebakaran hutan dan lahan. Kekompakan dalam kelompok ini diwujudkan dalam sikap saling menghargai antar anggota dan fokus pada tujuan dibentuknya kelompok sebagai petugas patroli pemadaman kebakaran.

\section{Bonding pada Kelompok Nelayan Harapan Bersama}

Kelompok Nelayan Harapan Bersama merupakan kelompok nelayan yang berada di Desa Pangkalan Jambi. Secara geografis, kelompok ini menempati wilayah pesisir dan identik dengan aktivitas nelayan baik berupa nelayan tangkap maupun kegiatan budi daya hasil laut seperti ikan dan mangrove. Secara kelembagaan, kelompok ini terbentuk karena adanya kesamaan profesi yaitu sebagai nelayan, kedekatan wilayah yang sama-sama tinggal di pesisir selat Bengkalis, serta adanya kesamaan adat istiadat Melayu yang masih kental di masyarakat. Adanya unsur kedekatan wilayah yang menjadi ciri khas relasi 
bonding juga sesuai dengan studi terdahulu yang menghubungkan mengenai kuatnya pengaruh kewilayahan terhadap relasi sosial yang timbul (Morsing, M,. Schutz 2006)

Dari 21 anggota kelompok, semuanya merupakan warga Desa Pangkalan Jambi yang berprofesi sebagai nelayan ataupun istri nelayan, selain itu semuanya merupakan suku Melayu. Hal ini dapat menjadi indikasi bahwa kesamaan atau homogenitas tersebut mendorong terbentuknya relasi bonding yang kuat antar anggota kelompok. Adanya latar belakang kesamaan suku yang terdapat pada Kelompok Nelayan Harapan Bersama juga menunjukkan eksistensi tradisi komunitarian. yang berlaku pada kelompok ini. Keberadaan kearifan lokal juga tercermin dari masih eksisnya ritual Turun Kapal sebagai bentuk syukur kepada Tuhan Yang Maha Esa sekaligus sebagai perwujudan solidaritas sesama nelayan.

Meskipun bukan didasari pada hubungan kekerabatan atau keluarga, namun kualitas relasi bonding yang kuat juga dapat ditemukan pada kelompok dengan kesamaan latar belakang profesi dan adat istiadat seperti yang terdapat pada kelompok ini. Hubungan yang terbangunpun cenderung bersifat kognitif (cognitive form) dengan melihat adanya peran pemimpin sosial (Social leader) yang kuat seperti imam masjid dan tokoh masyarakat dalam acara-acara kelompok. Pola-pola hubungan ini merupakan wujud dari norma sosial (norms) yang masih eksis sebagai penguat relasi bonding pada masyarakat nelayan.

Namun, sesuai karakteristiknya yang lebih menekan pada kesamaan latar belakang, kelompok ini juga cenderung untuk menolak anggota baru (out Group) untuk menjadi anggota kelompok dikarenakan alasan kekompakan kelompok. Sikap tersebut dapat dilihat juga sebagai bentuk perlindungan kelompok yang cenderung menolak keberadaan anggota baru dalam kelompok mereka. Sikap ini cenderung kuat pada kelompok-kelompok yang memiliki kesamaan latar belakang yang tinggi seperti kesamaan kekerabatan, kekeluargaan, kewilayahan dan kesukuan, seperti yang terlihat di Kelompok Nelayan Harapan Bersama.

\section{Relasi Bridging Masyarakat Binaan}

Relasi Bridging merupakan indikasi adanya koneksi sosial dalam kelompok yang beragam (heterogen) yang mendorong terciptanya inklusif sosial dari keberagaman populasi dan identitas. Relasi bridging timbul karena adanya 
keterbatasan sumber daya dari dalam kelompok sehingga untuk memenuhi kebutuhannya, kelompok perlu bekerja sama dengan kelompok lain guna memenuhi kebutuhan tersebut, hal ini menunjukkan bahwa relasi bridging didorong oleh adanya sikap kosmopolitan (Cosmopolitanism), dimana kelompok terdorong untuk mempraktikkan pengetahuan baru guna melengkapi keterbatasan yang dimilikinya. Dalam relasi bridging, titik beratnya adalah pada adanya hubungan yang setara (horizontal) antara satu kelompok atau individu dengan kelompok atau individu lain di luar mereka. Relasi yang terbentuk dari konsep bridging adalah jaringan sosial (SocialNetworks) yang menghubungkan antar kelompok untuk setidaknya bertukar informasi dan saling bekerja sama.

\section{Bridging pada Kelompok Tani Tunas Makmur dan Kelompok Masyarakat Peduli Api Desa Sungai Selari}

Dalam relasi bridging yang terbentuk antara Kelompok Tani Tunas Makmur dengan Kelompok Masyarakat Peduli Api Desa Sungai Selari didasarkan pada hubungan simbiosis mutualisme, dimana masing-masing kelompok saling membutuhkan peran dari kelompok lainnya. Seperti diketahui bahwa Kelompok Tani Tunas Makmur merupakan kelompok yang bergerak di bidang pertanian dan kehutanan dengan memanfaatkan lahan bekas kebakaran hutan yang ada di wilayah Sungai Pakning untuk dijadikan lahan pertanian nanas, sedangkan Kelompok Masyarakat Peduli Api Desa Sungai Selari merupakan kelompok yang dibentuk oleh Pemerintah Desa setempat untuk melakukan patroli dan pemadaman kebakaran pada tahap awal. Masing-masing memiliki kepentingan untuk mencegah kebakaran lahan karena akan merugikan kedua belah pihak, sedangkan menjaga agar lahan tidak terbakar akan menjadi keuntungan bagi kedua belah pihak (reciprocal benefits).

Meskipun begitu, relasi ini tercipta hanya karena adanya kebutuhan dari masing-masing pihak untuk mendapat manfaat dari keberadaan dan peran pihak lain, ini menunjukkan bahwa masing-masing kelompok sebenarnya tidak memiliki ikatan yang kuat (weak ties) yang mampu menjaga hubungan itu tetap berlangsung dalam waktu lama apabila masing-masing kelompok sudah tidak mendapat keuntungan lagi. Kekhawatiran ini didasarkan pada temuan bahwa relasi yang terjalin antara kedua kelompok ini lebih banyak diakibatkan karena adanya kesamaan aktivitas dalam menjaga lahan dari potensi kebakaran, sehingga 
apabila mitigasi kebakaran sudah menjadi kebiasaan masyarakat dan Kelompok Masyarakat Peduli Api kemudian sudah tidak melakukan patroli secara rutin, relasi bridging yang terjalin antar kedua kelompok ini juga diperkiraan akan semakin melemah.

\section{Bridging pada Kelompok Tani Tunas Makmur dan Kelompok Nelayan Harapan Bersama}

Relasi sosial bridging yang terbentuk di antara Kelompok Tani Tunas Makmur dan Kelompok Nelayan Harapan Bersama terwujud melalui kegiatankegiatan diskusi dan pembelajaran bersama berkaitan dengan pengembangan usaha kelompok. Sebagai kelompok yang lebih dulu di bina oleh Pertamina, Kelompok Tani Tunas Makmur sering berperan sebagai pembina bagi kelompok lain dalam hal pengembangan usaha dan penguatan kelembagaan, termasuk kepada Kelompok Nelayan Harapan Bersama.

Kegiatan berbagi pengetahuan ini dilakukan karena rasa kebersamaan yang terjalin di antara kelompok binaan dan fasilitasi yang dilakukan oleh Pertamina sehingga masing-masing kelompok merasa setara secara kedudukan. Meski begitu, hubungan yang terjadi antar kelompok lebih menunjukkan adanya hubungan transaksional berdasarkan kebutuhan terhadap sumber daya yang tidak dimiliki oleh kelompoknya namun dimiliki oleh kelompok lainnya. Hal ini berbeda dengan sikap kelompok ketika dihadapkan pada masyarakat di sekitar mereka yang ingin menjadi anggota baru kelompoknya, untuk menjadi anggota baru, kelompok lebih bersikap protektif atau menjaga supaya tidak sembarangan orang dapat masuk kelompok, namun apabila dilihat dari hubungan antar kelompok, kelompok lebih membuka diri untuk berhubungan dengan kelompok lain sejauh hubungan itu dapat memberikan keuntungan atau manfaat bagi kelompoknya.

Relasi bridging yang terbentuk antara kedua kelompok ini menandakan bahwa terdapat keterbatasan sumber daya yang ada di salah satu kelompok sehingga mengharuskan kelompok tersebut berhubungan dengan kelompok lain untuk dapat memenuhi sumber daya tersebut, hal ini menunjukkan adanya sikap kosmopolitan yang cukup kuat dari Kelompok Nelayan Harapan Bersama karena mau belajar dari kelompok lainnya, dalam hal ini adalah sumber daya 
pengetahuan yang belum dimiliki oleh Kelompok Nelayan Harapan Bersama sehingga membuat kelompok ini berelasi dengan Kelompok Tani Tunas Makmur.

\section{Bridging pada Kelompok Nelayan Harapan Bersama dan Kelompok Masyarakat Peduli Api Desa Sungai Selari}

Relasi bridging yang terjadi antara Kelompok Nelayan Harapan Bersama dan Kelompok MPA Sungai Selari tidak banyak ditemukan selama penelitian dilakukan. Dari hasil wawancara dengan kedua belah pihak, hubungan yang terjadi terbatas pada hubungan yang difasilitasi oleh Pertamina selaku pembina dalam kegiatan pemberdayaan masyarakat bagi kedua kelompok ini. Keterbatasan hubungan yang terjadi antara kedua kelompok ini dapat dilihat dari ketiadaan kepentingan bersama yang melatar belakangi timbulnya hubungan antar kedua kelompok. Dari sisi kewilayah, kedua kelompok ini juga tidak bersinggungan secara langsung, sehingga membuat kemungkinan relasi yang timbul karena kedekatan kewilayahan (area proximity) juga terbatas.

Ketiadaan relasi bridging yang kuat antara Kelompok Nelayan Harapan Bersama dan Kelompok MPA Sungai Selari dapat dipahami karena memang kedua kelompok ini tidak berbagi sumber daya untuk dapat menyelesaikan masalah bersama. Sehingga masing-masing kelompok tidak merasa perlu untuk mengikatkan diri satu sama lain dalam bentuk kohesi sosial yang kuat.

Secara ringkas, relasi bridging yang timbul antara masing-masing kelompok binaan adalah sebagai berikut:

Tabel 2: Karakteristik Relasi Bridging Masyarakat Binaan CSR PT Pertamina (Persero) RU II Kilang Sungai Pakning (Sumber: Data Peneliti, 2018)

\begin{tabular}{lllll}
\hline No & $\begin{array}{l}\text { Karakteristik } \\
\text { Relasi Bridging }\end{array}$ & $\begin{array}{l}\text { Kelompok } \\
\text { Tani Tunas } \\
\text { Makmur }\end{array}$ & $\begin{array}{l}\text { MPA Desa } \\
\text { Sungai } \\
\text { Selari }\end{array}$ & $\begin{array}{l}\text { Kelompok } \\
\text { Nelayan } \\
\text { Harapan } \\
\text { Bersama }\end{array}$ \\
\hline $\mathbf{1}$ & $\begin{array}{l}\text { Kelompok Tani } \\
\text { Tunas Makmur }\end{array}$ & - & $\begin{array}{l}\text { Koordinasi } \\
\text { Patroli } \\
\text { Pemenuhan } \\
\text { Tenaga Kerja }\end{array}$ & $\begin{array}{l}\text { Pelatihan } \\
\text { 2 Desa }\end{array}$ \\
$\mathbf{2}$ & $\begin{array}{l}\text { MPA Patroli } \\
\text { Sungai Selari } \\
\text { Penyediaan } \\
\text { Tenaga } \\
\text { Kerja } \\
\text { Pelatihan }\end{array}$ & - & Tidak Ada \\
& $\begin{array}{l}\text { Kelompok } \\
\text { Nelayan Harapan } \\
\text { Bersama }\end{array}$ & Tidak Ada & - \\
\hline
\end{tabular}




\section{Relasi Linking Masyarakat Binaan}

Relasi linking merupakan hubungan sosial yang terbentuk antara individu atau kelompok dengan individu atau kelompok kekuatan yang lebih tinggi dari mereka, individu atau kelompok kekuatan ini bisa berupa individu atau kelompok politik, individu atau kelompok keuangan, ataupun individu atau kelompok sosial yang lebih kuat dari kelompok mereka untuk dapat berhubungan dan mencapai tujuan bersama. Karakteristik relasi linking sebenarnya mirip dengan relasi bridging, karena keduanya sama-sama menghubungkan satu kelompok dengan kelompok lain di luar kelompok mereka (out Group) untuk dapat memenuhi sumber daya yang dibutuhkan dalam mencapai tujuan bersama, namun perbedaan yang cukup mencolok antara kedua relasi ini adalah apabila pada relasi bridging merupakan relasi yang setara (horizontal) antar kedua kelompok yang berhubungan, pada relasi linking yang terjadi adalah hubungan tidak setara antara kekuatan yang lebih kuat dengan kekuatan yang lebih lemah (vertikal) untuk dapat saling mencapai tujuan bersama. pada relasi Linking yang ditekankan adalah adanya sikap partisipatif (Participationism) dari berbagai pihak untuk terlibat dalam pemecahan suatu masalah.

Relasi linking memungkinkan munculnya interkoneksi dengan berbagai pihak yang memungkinkan untuk berbagi sumber daya guna mencapai tujuan pembangunan. Namun, interkoneksi yang diciptakan dari relasi Linking sangat tergantung pada ada tidaknya kesepakatan nilai-nilai antara kelompok-kelompok yang terlibat di dalamnya. Kesepakatan nilai-nilai ini misalnya ditunjukkan dengan kemauan untuk menjadi masyarakat binaan oleh suatu perusahaan dengan konsekuensi kelompok harus mengikuti program-program yang dilakukan oleh perusahaan. Kesepakatan seperti ini sangat kuat perannya dalam terjalinnya relasi linking.

Dalam penelitian ini, kelompok kekuatan yang dianggap memiliki kekuatan lebih besar dan dijadikan sebagai obyek penelitian adalah keberadaan PT Pertamina (Persero) RU II Sungai Pakning yang memiliki program CSR untuk membina Kelompok Tani Tunas Makmur, Kelompok Masyarakat Peduli Api Desa Sungai Selari, dan Kelompok Nelayan Harapan Bersama, meskipun tidak bisa dilepaskan juga mengenai keberadaan Pemerintah Daerah melalui Pemerintah Desa, Kelurahan, Kecamatan hingga Dinas terkait yang memiliki peran untuk 
melakukan pembinaan dan pendampingan terhadap masyarakat setempat. Namun dalam penelitian ini sesuai dengan batasan penelitian yang telah ditetapkan, peran Pemerintah Daerah akan dibatasi ulasannya sehingga lebih banyak mengulas mengenai peran Pertamina sebagai institusi yang memiliki kekuatan lebih besar dalam struktur sosial masyarakat.

\section{Model Relasi Bonding, Bridging dan Linking Masyarakat Binaan CSR PT}

\section{Pertamina (Persero) Refinery Unit II Kilang Sungai Pakning}

Dari beberapa pengamatan yang telah diulas sebelumnya, maka peneliti membuat model relasi Bonding, Bridging dan Linking untuk mempermudah dalam melihat dan memahami temuan atas penelitian ini sebagai berikut:

Gambar 1: Model Relasi Bonding, Bridging, dan Linking Masyarakat Binaan CSR PT Pertamina (Persero) Refinery Unit II Kilang Sungai Pakning Periode 2017-2018 dengan melihat kuat-lemah antar relasi. Semakin tebal garis menunjukkan relasi semakin kuat,semakin tipis garis menunjukkan relasi semakin lemah (Edelmen 2018)

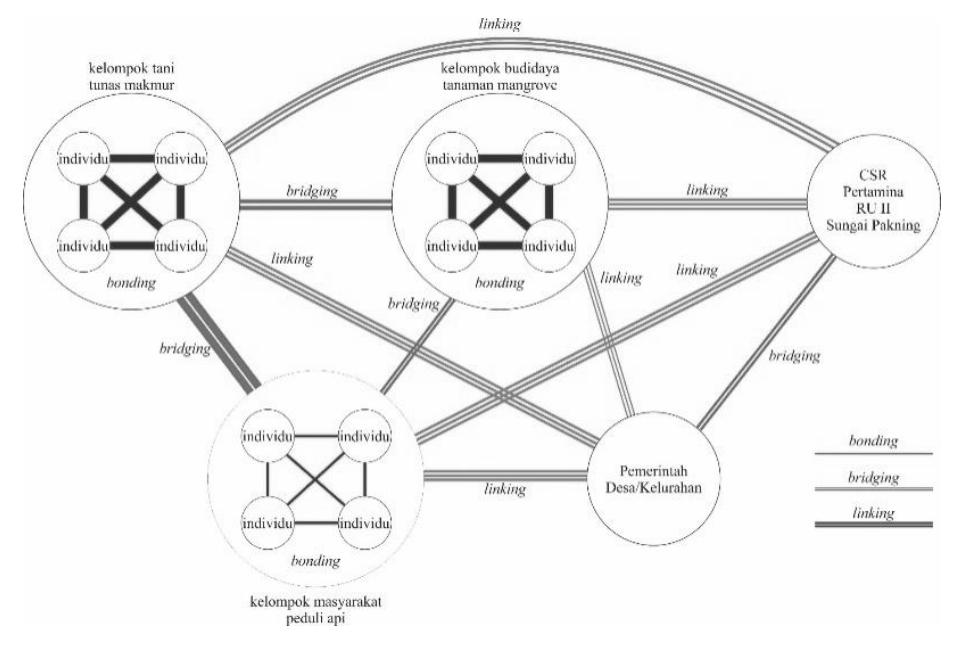

\section{Dampak Relasi Bonding, Bridging, dan Linking Masyarakat Binaan terhadap}

\section{Pelaksanaan CSR}

Dari temuan peneliti mengenai bentuk dan karakteristik relasi bonding, bridging dan linking yang ada di masyarakat binaan PT Pertamina (Persero) RU II Sungai Pakning, peneliti menemukan bahwa masing-masing relasi memiliki dampak yang positif dan negatif untuk masing-masing tingkatan relasi serta kelompok. 


\section{Dampak Relasi Bonding Masyarakat Binaan terhadap Pelaksanaan CSR PT Pertamina (Persero) RU II Kilang Sungai Pakning}

Secara umum, relasi bonding menunjukkan dampak yang kuat terhadap kohesi sosial dalam level internal kelompok. Pada jenis relasi ini, kesamaan latar belakang baik itu kesamaan asal wilayah, kesamaan profesi, dan kesamaan kesukuan memiliki dampak yang kuat dalam membentuk kesatuan dan rasa saling memiliki dalam masing-masing kelompok(Goodwind 2003). Relasi bonding yang sangat kuat teramati melalui aktivitas yang dilakukan oleh Kelompok Tani Tunas Makmur yang dilatar belakangi kesamaan kewilayahan dan keturunan dalam mengelola kegiatan pertanian nanas, jenis relasi ini juga cukup kuat muncul pada Kelompok Nelayan Harapan Bersama yang dilatar belakangi oleh semangat kesukuan, kewilayahan dan profesi yang sama. Meskipun pada Kelompok MPA Sungai Selari, relasi bonding tidak berdampak pada adanya kohesi sosial yang cukup kuat antar anggota, namun setidaknya relasi bonding pada kelompok ini yang didasari pada kesamaan profesi telah mampu menjaga soliditas kelompok dalam waktu yang cukup lama.

Dalam pelaksanaan CSR oleh Pertamina RU II Sungai Pakning, keberadaan relasi bonding yang kuat dalam masing-masing kelompok dapat membantu pengelola program untuk mengkoordinasi, mengkonsolidasi dan melaksanakan program-program CSR yang telah dirancang. Kekuatan relasi bonding juga terlihat dalam keterlibatan dan partisipasi aktif yang ditunjukkan oleh seluruh anggota kelompok dalam setiap pelaksanaan program CSR. Keterlibatan dan partisipasi aktif dari anggota kelompok ini terwujud karena tersedianya akses yang merata bagi setiap anggota kelompok untuk dapat terlibat dan kegiatankegiatan yang diselenggarakan oleh perusahaan. Relasi bonding juga terlihat memiliki dampak yang kuat terhadap eksistensi kerja-kerja bersama (collective Action). Kerja-kerja bersama ini tampak pada kekompakan dan kesukarelaan anggota kelompok untuk membantu anggota kelompok lain ataupun dalam bentuk gotong royong untuk merawat fasilitas umum yang ada di wilayah mereka.

Namun, karakteristik relasi bonding yang terlihat dari dua kelompok, yaitu Kelompok Tani Tunas Makmur dan Kelompok Nelayan Harapan Bersama yang cenderung menolak kehadiran anggota baru, dinilai cukup menghambat perkembangan kelembagaan yang diharapkan oleh pengelola CSR sebagai salah 
satu tolak ukur keberhasilan pelaksanaan program CSR. Padahal, di sisi lain, pertumbuhan jumlah anggota, perkembangan kelembagaan, dan pertukaran informasi antar kelompok menjadi salah satu indikator kuberhasilan pelaksanaan program CSR yang bertujuan untuk memberdayakan masyarakat.

\section{Dampak Relasi Bridging Masyarakat Binaan terhadap Pelaksanaan CSR PT Pertamina (Persero) RU II Kilang Sungai Pakning}

Relasi bridging memiliki karakteristik yang berbeda-beda untuk setiap kelompok. Pada Kelompok Tani Tunas Makmur, relasi bridging digunakan untuk memperkuat basis-basis pengelolaan pertanian yang menjadi kegiatan utama mereka. Relasi ini muncul sejalan dengan berkembangnya skala kegiatan yang dikelola oleh Kelompok Tani Tunas Makmur. Pada Kelompok MPA Sungai Selari, relasi bridging muncul sebagai akibat dari pelaksanaan CSR perusahaan yang menyelanggarakan program pemberdayaan dan membentuk forum antar MPA di Kecamatan tersebut. Relasi bridging kemudian mampu menjadi pendorong terbentuknya inklusi sosial antar sesama anggota MPA dari desa-desa terdekat untuk kemudian saling membantu dalam rangka kegiatan patroli kebakaran. Dalam pelaksanaan CSR, relasi bridging antar Kelompok MPA di masing-masing desa memudahkan pengelolaan program CSR karena lebih mudah dalam hal melakukan koordinasi dan pembinaan. Pengelola program CSR tidak lagi harus berhubungan dengan masing-masing Kelompok MPA, namun terpusat dalam satu wadah bersama yaitu Forum Komunikasi MPA (FORKOMPA) dan menjadikan komunikasi dan koordinasi program lebih efektif. Pada Kelompok Nelayan Harapan Bersama, relasi bridging justru muncul sebagai penyebab terjadinya program CSR yang dilakukan oleh perusahaan. Relasi bridging yang telah terjalin sebelumnya antar kelompok nelayan di wilayah itu membawa pengaruh yang positif terhadap keberadaan Kelompok Nelayan Harapan Bersama. Berkat relasi tersebut, Kelompok Nelayan Harapan Bersama dapat dikenal oleh Pertamina dan menjadi mitra binaan dalam melaksanakan program CSR di wilayah Desa Pangkalan Jambi. Ketiga kelompok menunjukkan perbedaan yang mendasar mengenai keberadaan relasi bridging dan dampak yang ditimbulkan dalam pelaksanaan CSR perusahaan. 


\section{Dampak Relasi Linking Masyarakat Binaan terhadap Pelaksanaan CSR PT Pertamina (Persero) RU II Kilang Sungai Pakning}

Relasi linking merupakan relasi yang diamati berperan sangat besar terhadap pelaksanaan CSR karena pada dasarnya melalui relasi inilah hubungan antara masing-masing kelompok dengan Pertamina selaku pembina dan pendamping pelaksanaan program CSR dapat terjalin dengan baik. Melalui relasi Linking inilah, kelompok mendapat tambahan pengetahuan, akses pemasaran, permodalan hingga penguatan kelembagaan untuk membuat keberadaan kelompok beserta relasi bonding dan bridging yang mereka miliki tidak terbuang sia-sia.

Meski begitu, kemunculan relasi linking pada masing-masing kelompok ternyata juga memiliki beberapa karakteristik yang berbeda. Apabila pada Kelompk MPA Sungai Selari, relasi linking merupakan penyebab yang diinisiasi oleh Pertamina untuk kemudian dapat menghubungkan dan menghidupkan relasi bridging antar kelompok MPA. Melalui relasi linking ini, perusahaan dapat melakukan pembinaan dan pendampingan kepada Kelompok MPA baik itu dari Desa Sungai Selari yang menjadi obyek dalam penelitian ini, maupun desa-desa lain yang memiliki relasi bridging

Selain itu, relasi linking juga memiliki karakteristik yang berbeda dalam Kelompok Nelayan Harapan Bersama, pada kelompok ini relasi linking muncul sebagai akibat dari keberadaan relasi bridging yang sudah lebih dulu ada di antara kelompok nelayan yang ada di wilayah itu. Dalam pelaksanaan CSR, munculnya relasi linking sebagai akibat dari keberadaan relasi bridging ini dinilai positif untuk menguatkan kelembagaan dan pertambahan jumlah anggota yang semakin banyak. Melalui relasi linking yang tumbuh secara alami dari kelompok, kelompok dapat menyampaikan pendapatnya mengenai keberadaan program dan pengembangan program berdasarkan sudut pandang kelompok (bottom up) dan Pertamina sebagai perusahaan pembina UMKM dapat lebih tepat dalam merancang dan menjalankan program-program pemberdayaan masyarakat karena relasi ini memungkinkan terbentuknya hubungan yang lebih dekat antara perusahaan dengan mitra binaan. 


\section{KESIMPULAN}

Penelitian mengenai relasi sosial khususnya yang melihat relasi sosial antara masyarakat binaan dengan perusahaan pelaku CSR belum banyak dilakukan di Indonesia. Penelitian ini merupakan upaya hilirisasi penelitian-penelitian tentang CSR yang sebelumnya banyak berkutat pada level kebijakan dan tataran makro semata menjadi lebih fokus pada aspek sosial kemasyarakatan yang memegang peran penting dalam keberhasilan praktik-praktik CSR yang dilakukan oleh korporasi.

Dari penelitian ini didapatkan deskripsi bahwa relasi sosial baik itu bonding, bridging dan linking yang ada di masyarakat memiliki dampak yang berbeda-beda dalam pengelolaan dinamika sosial di masyarakat. Relasi bonding perlu dipertahankan mengingat relasi ini merupakan penjaga kohesi sosial yang ada di masyarakat lokal. Sedangkan relasi bridging perlu dibangun oleh sesama kelompok masyarakat untuk menciptakan inklusi sosial yang lebih merata. Terakhir relasi linking memberikan kita gambaran bahwa sumber daya dari institusi sosial yang lebih kuat dapat dialirkan untuk membangun kesejahteraan masyarakat melalui terjalinnya relasi yang terbuka dan transparan antara masyarakat dengan institusi sosial yang ada di wilayah tersebut.

Gambaran mengenai ketiga relasi ini diharapkan dapat menjadi pijakan bahwa dalam level mikro, relasi sosial di masyarakat dapat begitu beragam sehingga para pengambil kebijakan atau praktisi CSR dapat mempertimbangkan untuk lebih tepat dalam memetakan relasi sosial yang ada di masyarakat dalam merancang program-program CSR atau program pembangunan lainnya.

\section{REFERENSI}

Colemen, J. 1999. "Social Capital in the Creation of Human Capital." Harvard University Press.

Cortado,F., Chalmeta, R. 2016. "Use of Social Network as a CSR Communication Tool." Cogent Business and Management 3:1-18.

Edelmen. 2018. “Trust: 2009 Edelman Trust Barometer.” 5 Mei 2018.

Elkington, J. 1997. “Cannibal with Forks.” Oxford.

Goodwind, N. R. 2003. Five Kinds of Capital:Useful Concept for Sustainable Development.

Morsing, M,. Schutz, M. 2006. "CSR Communication: Stakeholder Information, Response, and Involvement Strategies." Business Ethic :A European Review 15(4):323-38. 
Mutiah, Mutiah. 2017. "MEMBANGUN SISTEM KOMUNIKASI INDONESIA YANG KOLEKTIF LEWAT MEDIA TRADISIONAL." The Journal of Society \& Media 1(2):75-85.

Neuman, W. L. 2013. Metode Penelitian Sosial: Pendekatan Kualitatif Dan Kuantitatif Edisi Ke Tujuh. 7th ed. Jakarta.

Putnam, R. 1993. The Properus Community: Social Capital and Public Life. Edward Elgas Publishing.

Qudsy, S. .. 2015. Fenomena Dusun Kasuruan Dalam Lima Pendekatan Penelitian Kualitatif. Yogyakarta: Pustaka Pelajar.

Waddock,S. Googins, B. K. 2011. The Paradoxes of Comunication Corporate Social Responbility. edited by Blackwell Wiley. West Sussex.

Werther.J, Chandler, D. 2011. Strategic Corporate Social Responsibility: Stakeholders in Global Environment. California: Sage Publications.

Woolcock, M. 1998. "Social Capital and Economi Development: Towars a Theoritical Synthesis and Policy Framework." Theory and Society 27(2):151-208.

Woolcock, M. Narayan D. 2002. "Social Capital : Implication for Development Theory, Research, and Policy." The World Bank Researcy Observer Oxford University Press 15(2):225-49. 